\title{
Analisis Usahatani Padi Petani Peserta dan Non Peserta Lumbung Pangan Masyarakat (LPM) Di Kabupaten Pringsewu
}

\section{Analysis For Rice Farm of Participants Farmers and Non-Participants Farmers of Community Food Barn (LPM) In Pringsewu District}

\author{
Chriswin Riadinata ${ }^{1}$, Wan Abbas Zakaria ${ }^{2}$, Ktut Murniati ${ }^{3}$ \\ ${ }^{1,2,3}$ Faculty of Agriculture, Lampung University \\ *email: ewincr@gmail.com
}

\begin{abstract}
This study aims to analyze the differences in the income of rice farm of participant farmers and non-participant farmers of LPM. This research uses survey method. The research location was determined intentionally, namely in Gadingrejo District and Sukoharjo District. The respondents consisted of 74 farmers consisting of participant farmers and nonparticipant farmers of LPM. Data were analyzed descriptively quantitatively. The results showed that: rice farming income per hectare over cash costs in MT I, income of participant farmers amounted to Rp17,394,911.18 with cash costs incurred of Rp10,620,126.41 and non-participant farmers income was lower at Rp9,782,836, 93 with cash costs incurred in the amount of Rp10,583,397.21. In MT I, the $R$ / C ratio of rice farming to the total cost of participant farmers was 1.58 and the $R / C$ ratio of non-participant farmers was 1.12. The comparison of the $R$ / C ratio value of the total cost between participant farmers and nonparticipant farmers of LPM in MT I indicates that rice farming carried out by participant farmers is better, achieving greater profits compared to non-participant farmer farming. Results oft-test of rice farming income from the cash costs of participant farmers and nonparticipants farmers in MT I with a probability value (Sig. 2-tailed) of 0,000 means that the average income of rice farming on cash costs of participant farmers is significantly different from the income of rice farming on non-participant LPM farmer cash costs at 99 percent confidence level, as well as on MT II.
\end{abstract}

Keywords: farmers income, lpm, rice farm

Disubmit : 26 Juni 2020; Diterima: 18 September 2020; Disetujui : 29 Oktober 2020

\section{PENDAHULUAN}

Kegiatan pengembangan Lumbung Pangan Masyarakat (LPM) ditujukan untuk memantapkan keberadaan cadangan pangan di masyarakat dalam rangka mendekatkan akses pangan bagi masyarakat dan mendorong pengembangan usaha ekonomi produktif di bidang pangan (Badan Ketahanan Pangan Kementerian Pertanian 2019). Lumbung pangan berfungsi sebagai penyangga harga gabah, anggota kelompok lumbung pangan dapat meminjam gabah pada saat musim paceklik dan mengembalikannya pada saat panen raya. Petani tidak harus menjual seluruh gabahnya saat panen raya, ketika harga gabah cenderung rendah. Menurut Rachmat M (2010), lumbung pangan merupakan cadangan pangan yang berfungsi untuk menjaga stok atau stabilitas pangan baik karena musim paceklik atau karena ada kondisi darurat seperti 
bencana alam. Lumbung pangan individu berfungsi menyimpan stok bahan pangan rumah tangga selama periode tertentu. Lumbung kelompok berfungsi untuk mengatasi kerawanan pangan pada saat paceklik serta membantu anggota dalam penyediaan modal Prasmatiwi F.E., et al (2013).

Lumbung Pangan Masyarakat (LPM) tidak hanya sebagai kelembagaan pangan yang berfungsi menyediakan stok pangan masyarakat tapi juga mempunyai fungsi lain. Dengan adanya kelembagaan mendukung pembangunan pertanian Fitri et al (2018). Fungsi lain Lumbung Pangan Masyarakat (LPM) antara lain: (1) sebagai pusat informasi terkait kegiatan usahatani bagi petani, (2) memfasilitasi petani dalam berusahatani seperti penyediaan sarana produksi, (3) pendampingan petani dalam berusahatani, dan (4) koperasi simpan pinjam bagi petani. Fungsi LPM tersebut diharapkan dapat meningkatkan usahatani padi petani peserta sehingga pendapatan usahatani padinya akan lebih meningkat yang pada akhirnya dapat meningkatkan kesejahteraan.

Pemerintah Kabupaten Pringsewu melalui Dinas Ketahanan Pangan secara aktif berupaya menumbuhkan dan mengembangan kegiatan lumbung pangan melalui kegiatan Anggaran Pendapatan dan Belanja Daerah. Bantuan yang diberikan berupa bantuan pengisian sebanyak 1 ton per kelompok penerima, bantuan yang diberikan merupakan hibah yang berguna sebagai stimulan untuk penumbuhan lumbung pangan. LPM di Kabupaten Pringsewu. Informasi efektivitas program dalam meningkatkan tingkat pendapatan petani peserta LPM dan non-peserta belum tersedia. Oleh karena itu, perbandingan pendapatan usahatani peserta LPM dan non peserta LPM menjadi penting dilakukan. Penelitian ini bertujuan untuk menganalisis pendapatan usahatani padi petani peserta dan nonpeserta Lumbung Pangan Masyarakat di Kabupaten Pringsewu.

\section{METODE PENELITIAN}

Penelitian ini dilakukan menggunakan metode survei. Menurut Sukardi (2007), metode survei merupakan metode yang bertujuan untuk memperoleh gambaran umum tentang karakteristik populasi yang digambarkan oleh sampel. Metode ini digunakan karena penelitian ini mengambil sampel dari populasi di daerah penelitian.

Responden penelitian adalah petani padi peserta dan petani nonpeserta Lumbung Pangan Masyarakat (LPM). Penelitian ini mengambil responden dari kedua kelompok tersebut, karena akan dilakukan perbandingan antara petani peserta dan non peserta Lumbung Pangan Masyarakat (LPM). Petani-petani tersebut berada di Kecamatan Gading Rejo dan Sukoharjo dengan pertimbangan kecamatan tersebut adalah sentral Lumbung Pangan Masyarakat (LPM) di Kabupaten Pringsewu. Jumlah populasi petani padi sawah di kedua kecamatan tersebut berjumlah 7.069 petani peserta. Metode pengambilan sampel dilakukan dengan menggunakan metode acak sederhana dengan menggunakan rumus perhitungan sampel menurut (Sugiarto, D. S., Sunaryanto, L.T. dan Oetomo 2003), diperoleh hasil sebagai berikut:

$$
n=\frac{N Z^{2} S}{N d^{2}+Z^{2} S^{2}}
$$

\section{Keterangan:}

$$
\begin{array}{ll}
\mathrm{n} & \text { : Jumlah sampel } \\
\mathrm{N} & \text { : Jumlah populasi } 7.069 \text { (orang) } \\
\mathrm{Z} & \text { : Tingkat kepercayaan } 95 \%(1,96) \\
\mathrm{S}^{2} & \text { : Varian sampel }(5 \%) \\
\mathrm{d} & \text { : Derajat penyimpangan }(5 \%)
\end{array}
$$


Analisis pendapatan usahatani dihitung berdasarkan kondisi per hektar luas tanam baik musim tanam pertama maupun kedua. Analisis pendapatan petani peserta LPM dan non peserta LPM dalam usahatani padi dapat dihitung dengan menggunakan rumus sebagai berikut:

$u=\mathrm{Y} . \mathrm{Py}-\sum \mathrm{Xi} . \mathrm{Pxi}-\mathrm{BTT}$

\section{Keterngan:}

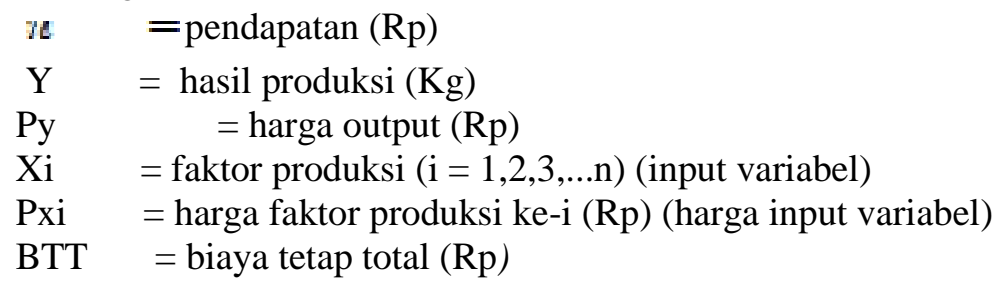

Selanjutnya untuk mengetahui usahatani menguntungkan atau tidak secara ekonomi dapat dianalisis dengan menggunakan nisbah atau perbandingan antara penerimaan dengan biaya R/C (Revenue Cost Ratio). Secara matematis R/C dapat dituliskan :

$\mathrm{R} / \mathrm{C}=\mathrm{PT} / \mathrm{BT}$

Keterangan :

$\mathrm{R} / \mathrm{C}=$ nisbah penerimaan dan biaya

$\mathrm{PT} \quad=$ penerimaan total $(\mathrm{Rp})$

$\mathrm{BT} \quad=$ Biaya total $(\mathrm{Rp})$

Kriteria pengambilan keputusan untuk mengetahui apakah usahatani padi menguntungkan atau tidak, terdapat tiga kemungkinan yang akan terjadi yaitu:

a. Jika $\mathrm{R} / \mathrm{C}>1$, maka usahatani mengalami keuntungan, karena penerimaan lebih besar dari biaya.

b. Jika R/C $<1$, maka usahatani mengalami kerugian, karena penerimaan lebih kecil dari biaya.

c. Jika $\mathrm{R} / \mathrm{C}=1$, maka usahatani yang dilakukan berada pada titik impas atau penerimaan sama dengan biaya yang dikeluarkan.

Pada analisis dengan menggunakan nisbah atau perbandingan antara penerimaan dengan biaya $\mathrm{R} / \mathrm{C}$ (Revenue Cost Ratio) dapat dilihat nisbah penerimaan terhadap biaya tunai dan biaya total (Soekartawi 2002) .

Untuk mengetahui perbedaan pendapatan usahatani padi peserta dan nonpeserta LPM baik musim tanam pertama maupun kedua., dilakukan uji beda dengan menggunakan hipotesis sebagai berikut:

a. $\mathrm{H}_{0}: \mu_{1}=\mu_{2}$ artinya rata-rata pendapatan usahatani padi antara petani peserta dan non peserta LPM sama saja.

b. $\mathrm{H}_{1}: \mu_{1} \neq \mu_{2}$ artinya rata-rata pendapatan usahatani padi petani peserta dan non peserta LPM berbeda.

Hipotesis di atas diuji dengan t-test dua sampel, dimana rumus yang digunakan adalah sebagai berikut: thitung $=\frac{\overline{x_{1}}-\overline{x_{2}}}{\sqrt{\frac{s_{1}^{2}}{n_{1}}+\frac{s_{2}^{2}}{n_{2}}}}$

Keterangan :

$\mathrm{x}_{1} \quad=$ rata-rata pendapatan usahatatani padi petani peserta LPM

$\mathrm{x}_{2} \quad=$ rata-rata pendapatan usahatatani padi non peserta LPM

$\mathrm{S}_{1} \quad=$ standar deviasi pendapatan usahatatani padi padi petani peserta LPM

$\mathrm{S}_{2} \quad=$ standar deviasi pendapatan usahatani padi petani non peserta LPM 


\section{HASIL DAN PEMBAHASAN}

Pendapatan usahatani padi petani peserta dan nonpeserta LPM merupakan selisih antara penerimaan petani dikurangi dengan biaya-biaya usahatani. Analisis pendapatan usahatani padi petani peserta dan nonpeserta LPM pada MT I dan MT II disajikan pada Tabel 1. Pendapatan usahatani menurut Gustiyana (2004), dapat dibagi menjadi dua, yaitu (1) pendapatan kotor, yaitu seluruh pendapatan yang diperoleh petani dalam usahatani selama satu tahun yang dapat diperhitungkan dari hasil penjualan yang dinilai dalam rupiah berdasarkan harga per satuan berat pada saat pemungutan hasil, (2) pendapatan bersih, yaitu seluruh pendapatan yang diperoleh petani dalam satu tahun dikurangi dengan biaya produksi selama proses produksi.

Tabel 1 menunjukkan bahwa pendapatan usahatani padi per hektar atas biaya tunai pada MT I, pendapatan petani peserta LPM sebesar Rp17.394.911,18 dengan biaya tunai yang dikeluarkan sebesar Rp10.620.126,41 dan pendapatan petani nonpeserta LPM lebih rendah yaitu sebesar Rp9.782.836,93 dengan biaya tunai yang dikeluarkan sebesar Rp10.583.397,21. Pendapatan usahatani padi per hektar atas biaya total pada MT I, pendapatan petani peserta LPM sebesar Rp10.302.070,56 dengan biaya total yang digunakan sebesar Rp17.712.967,03 dan pendapatan petani nonpeserta LPM lebih rendah yaitu sebesar Rp2.249.793,11 dengan biaya total yang digunakan sebesar Rp18.116.441,04.

Tabel 1. Analisa pendapatan usahatani padi petani peserta dan nonpeserta LPM pada MT I dan MT II

\begin{tabular}{|c|c|c|c|c|}
\hline \multirow{2}{*}{ Keterangan } & \multicolumn{2}{|c|}{ MT I } & \multicolumn{2}{|c|}{ MT II } \\
\hline & Per Usahatani & Per Hektar & Per Usahatani & Per Hektar \\
\hline \multicolumn{5}{|l|}{ Peserta LPM } \\
\hline Penerimaan ( $\mathrm{Rp}$ ) & $19.610 .526,32$ & $28.015 .037,59$ & $17.316 .799,56$ & $24.738 .285,09$ \\
\hline Produksi (Kg) & $3.735,34$ & $5.336,20$ & $3.223,31$ & $4.604,73$ \\
\hline Harga (Rp) & $5.250,00$ & $5,250,00$ & $5.372,37$ & $5.372,37$ \\
\hline \multicolumn{5}{|l|}{ Biaya (Rp) } \\
\hline Biaya Tunai (Rp) & $7.432 .192,48$ & $10.620 .126,41$ & $7.148 .438,78$ & $10.212 .055,40$ \\
\hline Biaya Total (Rp) & $12.396 .867,14$ & $17.712 .967,03$ & $11.973,023,21$ & $17,104.318,87$ \\
\hline \multicolumn{5}{|l|}{ Pendapatan (Rp) } \\
\hline Atas biaya tunai (Rp) & $12.178 .333,83$ & $17,394.911,18$ & $10.168 .360,78$ & $14,526.229,69$ \\
\hline Atas biaya total ( $R p)$ & $7.213 .659,18$ & $10.302 .070,56$ & $5.343 .776,35$ & $7.633 .966,22$ \\
\hline Nonpeserta LPM & 0,57 & & 0,57 & \\
\hline Penerimaan ( $R p)$ & $11.608 .753,46$ & $20.366 .234,14$ & $10.997 .297,19$ & 19.293 .503 .84 \\
\hline Produksi (Kg) & $2.652,63$ & $4,653,74$ & $2.286,09$ & $4.010,68$ \\
\hline Harga (Rp) & $4,376,32$ & $4.376,32$ & $4.810,53$ & $4.810,53$ \\
\hline \multicolumn{5}{|l|}{ Biaya (Rp) } \\
\hline Biaya Turai (Rp) & $6.031 .054,93$ & $10.583 .397,21$ & $5.830,561,54$ & $10.213 .267,54$ \\
\hline Biaya Total (Rp) & $10.328 .697,88$ & $18,116,441,04$ & $10.059 .776,63$ & $17.632 .943,13$ \\
\hline \multicolumn{5}{|l|}{ Pendapatan ( $R p)$} \\
\hline Atas biaya tunai (Rp) & $5.577 .698,53$ & $9.782 .836,93$ & $5.166 .735,65$ & 9.080 .236 .31 \\
\hline Atas biaya total $(\mathrm{Rp})$ & $1.280 .055,59$ & $2.249 .793,11$ & $937.520,56$ & $1.660 .560,71$ \\
\hline
\end{tabular}

Selanjutnya untuk melihat apakah usahatani padi petani peserta LPM dan petani nonpeserta LPM pada MT I menguntungkan atau tidak dilakukan analisis $R / C$ ratio. Nilai $R / C$ ratio yang lebih besar dari satu (R/C $>1$ ) baik pada usahatani padi petani peserta ataupun petani nonpeserta LPM berarti bahwa usahatani padi di Kabupaten Pringsewu menguntungkan untuk diusahakan. Pada MT I nilai $R / C$ ratio usahatani padi atas biaya total petani peserta LPM sebesar 1,58 dan nilai $R / C$ ratio usahatani padi petani nonpeserta LPM sebesar 1,12. Perbandingan nilai $R / C$ ratio atas biaya total antara usahatani padi petani peserta LPM dan nonpeserta LPM 
pada MT I ini mengindikasikan bahwa usahatani padi yang dilaksanakan oleh petani peserta LPM lebih baik, meraih keuntungan yang lebih besar dibandingkan usahatani petani nonpeserta LPM.

Tabel 1 menjelaskan juga bahwa pendapatan usahatani padi per hektar atas biaya tunai pada MT II, pendapatan petani peserta LPM sebesar Rp14.526.229,69 dengan biaya tunai yang dikeluarkan sebesar Rp10.212.055,40 sedangkan pendapatan petani nonpeserta LPM lebih rendah yaitu sebesar Rp9.080.236,31 dengan biaya tunai yang dikeluarkan sebesar Rp10.213.267,54. Pendapatan usahatani padi per hektar atas biaya total pada MT II, pendapatan petani peserta LPM sebesar Rp7.633.966,22 dengan biaya total yang digunakan sebesar Rp17.104.318,87 sedangkan pendapatan petani nonpeserta lebih rendah yaitu sebesar Rp1.660.560,71 dengan biaya total yang digunakan sebesar Rp17.632.943,13.

Pada MT II nilai $R / C$ ratio usahatani padi atas biaya total petani peserta LPM sebesar 1,45 dan nilai $R / C$ ratio petani nonpeserta LPM sebesar 1,09 . Perbandingan nilai $R / C$ ratio atas biaya total antara usahatani padi petani peserta LPM dan nonpeserta LPM pada MT II ini mengindikasikan bahwa usahatani padi yang dilaksanakan oleh petani peserta LPM masih lebih baik, meraih keuntungan yang lebih besar dibandingkan usahatani petani nonpeserta LPM.

Berdasarkan uji beda statistik terdapat perbedaan pendapatan yang nyata antara usahatani padi petani peserta LPM dan petani nonpeserta LPM baik pendapataan atas biaya tunai maupun pendapatan atas biaya total pada MT I dan MT II. Hasil uji beda pendapatan usahatani padi atas biaya tunai petani peserta dan nonpeserta LPM pada MT I dan MT II dapat dilihat pada Tabel 2.

Tabel 2. Uji beda pendapatan usahatani padi atas biaya tunai petani peserta dan nonpeserta LPM pada MT I dan MT II

\begin{tabular}{|c|c|c|c|c|}
\hline \multirow{2}{*}{ Uraian } & \multicolumn{2}{|c|}{ Musim Tanam I } & \multicolumn{2}{|c|}{ Musim Tanam II } \\
\hline & Peserta LPM & Nonpeserta LPM & Peserta LPM & Nonpeserta LPM \\
\hline Pendapatan (Rp) & $17.394 .911,18$ & $9.782 .836,93$ & $14.526 .229,69$ & $9.080 .236,31$ \\
\hline t-hitung & \multicolumn{2}{|c|}{5,938} & \multicolumn{2}{|c|}{5,711} \\
\hline Sig. (2-tailed) & \multicolumn{2}{|c|}{0,000} & \multicolumn{2}{|c|}{0,000} \\
\hline
\end{tabular}

Hasil uji beda pendapatan usahatani padi atas biaya tunai petani peserta dan nonpeserta LPM pada MT I dan MT II. Pada MT I nilai probabilitas (Sig. 2-tailed) sebesar 0,000 artinya rata-rata pendapatan usahatani padi atas biaya tunai petani peserta LPM sebesar Rp17.394.911,18 berbeda nyata dengan pendapatan usahatani padi atas biaya tunai petani nonpeserta LPM sebesar Rp9.782.836,93 pada tingkat kepercayaan 99 persen. Demikian juga dengan hasil uji beda pendapatan usahatani padi atas biaya tunai petani peserta dan nonpeserta LPM pada MT II dengan nilai probabilitas (Sig. 2-tailed) sebesar 0,000 artinya rata-rata pendapatan tunai usaha tani padi petani peserta LPM sebesar Rp18.177.287,86 berbeda nyata dengan rata-rata pendapatan tunai usahatani petani nonpeserta LPM sebesar Rp 13.158.455,61 pada tingkat kepercayaan 99 persen.

Data hasil uji beda pendapatan atas biaya total usahatani padi petani peserta dan nonpeserta LPM pada MT I dan MT II dapat dilihat pada Tabel 3.

Tabel 3. Uji beda pendapatan atas biaya total usahatani padi petani peserta dan nonpeserta LPM pada MT I dan MT II

\begin{tabular}{lcccr}
\hline \multirow{2}{*}{ Lraian } & \multicolumn{2}{c}{ Musim TanamI } & \multicolumn{2}{c}{ Musim TanamII } \\
\cline { 2 - 5 } & Peserta LPM & Nonpeserta LPM & Peserta LPM & Nonpeserta LPM \\
\hline Pendapatan (Rp) & $10.302 .070,56$ & $2.249 .793,11$ & $7.633 .966,22$ & $1.660 .560,71$ \\
t-hitung & \multicolumn{2}{c}{8,221} & \multicolumn{2}{c}{9,177} \\
Sig (2-tailed) & \multicolumn{2}{c}{0,000} \\
\hline
\end{tabular}

Hal 96 Volume 4, Nomor 2,Tahun 2020 
Hasil uji beda pendapatan atas biaya total usahatani padi petani peserta dan nonpeserta LPM pada MT I dan MT II. Pada MT I nilai probabilitas (Sig. 2-tailed) sebesar 0,000 artinya rata-rata pendapatan total usaha tani padi petani peserta LPM sebesar Rp. 14.370.572,19 berbeda nyata dengan rata-rata pendapatan atas biaya total usahatani padi petani nonpeserta LPM sebesar Rp 5.900.173,32 pada tingkat kepercayaan 99 persen.

Begitu juga dengan hasil uji beda pendapatan atas biaya total usaha tani padi petani peserta dan nonpeserta LPM pada MT II dengan nilai probabilitas (Sig. 2-tailed) sebesar 0,000 artinya rata-rata pendapatan atas biaya total usaha tani padi petani peserta LPM sebesar Rp. 12.277.505,59 berbeda nyata dengan rata-rata pendapatan atas biaya total usahatani padi petani nonpeserta LPM sebesar Rp 6.454.151,00 pada tingkat kepercayaan 99 persen

Baik pada MT I maupun MT II penghasilan dari usahatani padi peserta LPM lebih besar dari petani nonpeserta LPM. Hal ini menunjukkan bahwa program LPM berperan penting dalam upaya peningkatan pendapatan peserta program dibanding non-LPM. Hal ini sejalan dengan hasil penelitian Kasogi et al. (2014) yang menyatakan bahwa menjadi anggota kelompok tani memberikan manfaat dalam peningkatan pendapatan usahatani padi petani yang dilihat dari perbedaan pendapatan antara petani anggota dengan petani non-anggota kelompok tani yang menunjukkan pendapatan petani anggota lebih tinggi dari pendapatan usahatani non-anggota kelompok tani.

Melihat perbedaan yang nyata antara pendapatan usahatani padi petani peserta LPM dan petani nonpeserta LPM dari penelitian ini, penedliti melihat hal ini dipengaruhi oleh 2 faktor utama yaitu perbedaan rata-rata luas lahan usatani dan nilai harga jual hasil produksi, dimana keberadaan LPM mempunyai posisi tawar yang cukup kuat untuk dapat mengatur kapan melakukan penjualan hail produksi anggotanya. Handayani et al (2017) dalam penelitiannya menyatakan bahwa faktor luas lahan berpengaruh nyata terhadap produksi padi pada tingkat kepercayaan 99,9 persen, begitu juga Sugesti et el, (2015) dalam penelitiannya menyatakan bahwa semakin luas lahan yang digarap oleh petani, maka pendapatan yang akan diperoleh akan semakin tinggi, dan dalam penelitian yang dilakukan oleh Zahara et al, (2016) menyimpulkan bahwa faktor-faktor yang memiliki hubungan yang signifikan terhadap pendapatan usahatani padi adalah variabel pengalaman usahatani, produksi dan harga.

\section{KESIMPULAN DAN SARAN}

Terdapat perbedaan pendapatan usahatani padi petani peserta dan petani nonpeserta Lumbung Pangan Masyarakat (LPM) di Kabupaten Pringsewu baik pada MT I maupun MT II. Pada MT I maupun MT II pendapatan atas biaya tunai dan pendapatan atas biaya total usahatani padi petani peserta LPM lebih tinggi dibandingkan dengan petani nonpeserta LPM. Berdasarkan hasil penelitian, maka keberlanjutan LPM program/kegiatan bantuan pemerintah yang secara positif meningkatkan pendapatan usahatani padi perlu terus dipertahankan dan ditingkatkan kapasitas kelembagaannya. Dukungan segenap pihak dalam lembaga Poktan dan Gapoktan serta pihak-pihak terkait sangat diperlukan dalam menjaga fungsi dan peran LPM bekerja. LPM sangat diperlukan untuk memantapkan keberadaan cadangan pangan di masyarakat. Lebih lanjut, masyarakat petani dapat lebih mengembangkan usaha ekonomi produktif yang bernilai tambah berdasar pada produk-produk pangan lokal seperti padi, ubi kayu, jagung, ubi jalar, dll, sehingga sumbersumber pendapatan masyarakat perdesaan semakin berkembang dan perekonomian desa menjadi maju. Pembahasan lebih lanjut mengenai peranan kelembagaan LPM dan partisipasinya dalam meningkatkan ketahanan pangan hingga level rumah tangga dan individu dapat menjadi langkah penelitian lanjutannya.. 


\section{DAFTAR PUSTAKA}

Badan Ketahanan Pangan Kementerian Pertanian. 2019. Keputusan Kepala Badan Ketahanan Pangan Nomor: 55/KPTS/RC.110/J/12/2018 Tentang Petunjuk Teknis Pengembangan Lumbung Pangan Masyarakat Tahun 2019." Jakarta (ID.

Fitri, Annisa, Harianto Harianto, and Ratna Winandi Asmarantaka. 2018. "Analisis Pendapatan Usahatani Sawi Pola Kemitraan Dan Non Mitra Di Kecamatan Megamendung Kabupaten Bogor Jawa Barat." Journal of Food System \& Agribusiness 2(2): 94-99.

Handayani Siti Asih. Irwan Effendi. Begem Viantimala. 2017. "Produksi Dan Pendapatan Usahatani Padi Di Desa Pujo Asri Kecamatan Trimurjo Kabupaten Lampung Tengah.” Jiia 5(4): 422-29.

Muhammad Iqbal Kasogi. Dyah Aring Hepiana Lestari. Novi Rosanti. 2014. "Manfaat Berkelompoktani Dalam Meningkatkan Pendapatan Dan Efisiensi Ekonomi Relatif Usahatani Padi Di Desa Negara Ratu Kecamatan Natar Kabupaten Lampung Selatan.” JIIA, 2(4): 323-30.

Prasmatiwi F.E., Rosanti, and Dan Listiana. 2013. "Kajian Cadangan Pangan Rumah Tangga Petani Padi Di Provinsi Lampung" In Prosiding Seminar Nasional Sains Dan Teknologi V (Satek Dan Lndonesia Hijau), Bandar Lampung (ID): Lembaga Penelitian Universitas Lampung, 1103-12.

Rachmat M. 2010. Kajian Sistem Kelembagaan Cadangan Pangan Masyarakat Perdesaan Untuk Mengurangi 25\% Risiko Kerawanan Pangan. Jakarta (ID): Departemen Pertanian.

Soekartawi. 2002. Prinsip Dasar Ekonomi Pertanian. Jakarta: Raja Grafindo Persada.

Sugesti, Mei Tri, Zainal Abidin, and Umi Kalsum. 2015. "Analisis Pendapatan Dan Pengeluaran Rumah Tangga Petani Padi Desa Sukajawa, Kecamatan Bumiratu Nuban, Kabupaten Lampung Tengah.” Jurnal Ilmu-Ilmu Agribisnis 3(3): 268-76.

Sugiarto, D. S., Sunaryanto, L.T. dan Oetomo, D.S. 2003. Teknik Sampling. Jakarta (ID): Gramedia Pustaka Utama.

Sukardi. 2007. Metodologi Penelitian Pendidikan Kompetensi Dan Praktiknya. Jakarta (ID): PT Bumi Aksara.

Zahara, Rahadian Mawardi dan Arfi Irawati. 2016. “Analisis Biaya, Pendapatan Dan Faktor-Faktor Yang Berhubungan Dengan Pendapatan Usahatani Padi Di Kabupaten Pringsewu." Prosiding Seminar Nasional Agroinovasi Spesifik Lokasi Untuk Ketahanan Pangan Pada Era Masyarakat Ekonomi ASEAN (1): 1604-10. 